\title{
Isolation of planctomycetes from Aplysina sponges
}

\author{
Sheila Pimentel-Elardo ${ }^{1,2}$, Markus Wehrl ${ }^{1}$, Anja B. Friedrich ${ }^{1}$, Paul R. Jensen ${ }^{3}$, \\ Ute Hentschel ${ }^{1, *}$ \\ ${ }^{1}$ Institut für Molekulare Infektionsbiologie, Universität Würzburg, Röntgenring 11, 97070 Würzburg, Germany \\ ${ }^{2}$ College of Pharmacy, University of San Carlos, Cebu City 6000, Philippines \\ ${ }^{3}$ Center for Marine Biotechnology and Biomedicine, Scripps Institution of Oceanography, University of California, \\ San Diego, La Jolla, California 92093, USA
}

\begin{abstract}
There is mounting molecular evidence that bacteria belonging to the phylum Planctomycetes are abundant in marine sponges including members of the genus Aplysina. In an attempt to culture planctomycete bacteria from Aplysina sponges, 116 bacterial strains were isolated on selective oligotrophic media. Screening of the strain collection by fluorescence in situ hybridization with the planctomycete-specific probe Pla46 yielded 3 positive candidates. Nearly complete sequencing of the respective 16S rRNA genes revealed that the isolates were affiliated with 2 distinct clusters of the genus Pirellula: 1 isolate was obtained from a Mediterranean sponge, 1 from a Caribbean sponge and a third from Caribbean seawater. To our knowledge this is the first report of cultured Planctomycetes from marine sponges. The isolates grew slowly on oligotrophic media and failed to grow on nutrientrich media. Pirellula sp. Strain 797 was pink-pigmented while the other 2 isolates, 16 and 81, were non-pigmented. Transmission electron microscopy revealed a pear- or droplet-shaped cell morphology that is characteristic of the genus Pirellula. The application of strain-specific oligonucleotide probes to sponge tissue cryosections showed that the isolates contribute only a minor fraction to the total microbial community that is associated with Aplysina spp. sponges.
\end{abstract}

KEY WORDS: Pirellula · Planctomycete · Aplysina · Sponge · Porifera · Sponge-associated microorganism $\cdot 16 \mathrm{~S}$ rDNA

\section{INTRODUCTION}

The planctomycetes form a phylum within the domain Bacteria that is characterized by a peptidoglycanfree cell wall, cell compartmentalization due to the presence of a membrane-bound nucleoid (Lindsay et al. 1997, 2001), a short 5S rRNA sequence, as well as a budding mode of reproduction (for review see Fuerst 1995). Currently, there are 4 known genera, the Planctomyces, Gemmata, Isosphaera and Pirellula. They were originally discovered as freshwater planktonic organisms and have subsequently been found in a variety of marine, hypersaline, freshwater and terrestrial environments (Schlesner 1986, Ward et al. 1995, Wang et al. 2002). With the aid of selective cultivation media and the application of molecular microbial ecology tools, their natural abundances are becoming increasingly known (Liesack \& Stackebrandt 1992, Neef et al. 1998, Derakshani et al. 2001). However, because the typical marine media (e.g. ZoBell's medium) are inhibitory to the growth of planctomycetes, few have been cultivated from the marine environment. Accordingly, the development of improved methods for the cultivation of these and other oligotrophic bacteria is still a challenging task.

There is mounting evidence that planctomycete bacteria occur within marine sponges. Fuerst et al. (1998, 1999) described 6 distinct morphotypes in various tropical sponges. All of these bacteria shared the presence of 'membrane-bound nuclear bodies', a feature that is so far unique to the planctomycete division. In contrast to classical planctomycetes, the sponge-associated bacteria appear to lack polar differentiation (lack of a polar cap). Because the cell walls of these sponge- 
associated bacteria resemble an S-layer-type membrane, an affiliation with the Archaea has been proposed (Fuerst et al. 1999). Bacteria with nucleoid-like structures have also been identified in the mesohyl matrix of Mediterranean verongid sponges (Vacelet 1975, Friedrich 1998, Friedrich et al. 1999). Moreover, in situ hybridization with the planctomycete-specific probe Pla46 produced abundant fluorescent signals in Aplysina aerophoba (Friedrich et al. 2001) and the Australian sponge Rhopaloides odorabile (Webster et al. 2001), suggesting that planctomycetes may be a numerically important component of the sponge microbiota. The aim of this study was to cultivate planctomycetes from Aplysina spp. sponges, to determine their phylogenetic affiliation by $16 \mathrm{~S}$ rRNA genes sequencing and to verify their presence in sponge tissues by the application of strain-specific oligonucleotide probes.

\section{MATERIALS AND METHODS}

Sponge collection. Aplysina aerophoba sponges (class Demospongiae, order Verongida, family Aplysinidae) were collected by SCUBA diving at depths of 5 to $15 \mathrm{~m}$ offshore of Banyuls-sur-Mer, France (GPS: $42^{\circ} 29^{\prime} \mathrm{N}, 03^{\circ} 08^{\prime} \mathrm{E}$ ) in May 2000. The sponges $A$. fistularis, $A$. insularis and $A$. archeri were collected by SCUBA diving during a research expedition to the Bahamas with the RV 'Seward Johnson', of the Harbor Branch Oceanographic Institution (HBOI), USA, in August 2000. Samples were collected offshore of Little San Salvador island (GPS: $24^{\circ} 32.68^{\prime} \mathrm{N}, 75^{\circ} 55.73^{\prime} \mathrm{W}$ ). Seawater and sediment samples were taken from the immediate vicinity of the sponges as controls to see whether putative planctomycete isolates would be sponge-specific. The samples were processed immediately after collection using ship-board laboratory facilities. The remaining sponge samples were frozen for future fluorescence in situ hybridization (FISH) studies.

Microbial isolation and cultivation. Sponge tissues were excised from the center of individual sponge samples using an alcohol-sterilized cork borer, and the ends were removed with a scalpel. Tissues were rinsed $3 \times$ in sterile seawater, minced with a razor blade, and homogenized with a Dounce homogenizer. Sponge tissues were also plated prior to homogenization using a sterile glass rod and plate spinner. Homogenates of sponge tissues were diluted with sterile seawater from $10^{-1}$ to $10^{-5}$ and $3 \times 100 \mu \mathrm{l}$ were plated on the following media $\left(\mathrm{l}^{-1}\right)$ : M13 (peptone $0.25 \mathrm{~g}$, yeast extract $0.25 \mathrm{~g}$, glucose $0.25 \mathrm{~g}$, agar $18 \mathrm{~g}$, distilled water $750 \mathrm{ml}$, artificial seawater $250 \mathrm{ml}$ ) and M30a (Solution 1: Hunter's basal salts $20 \mathrm{ml}, 0.1 \mathrm{M}$ Tris $\mathrm{HCl}$ pH $7.550 \mathrm{ml}$, agar 18 $\mathrm{g}$, artificial seawater $250 \mathrm{ml}$, distilled water $630 \mathrm{ml}$;
Solution 2: $N$-acetylglucosamine $2.0 \mathrm{~g}$, sodium phosphate $0.1 \mathrm{~g}$, vitamin solution $5 \mathrm{ml}$, distilled water $45 \mathrm{ml}$ ) (Schlesner 1994), oligotrophic agar (Santavy et al. 1990) and seawater agar (agar 15 g, artificial seawater $1000 \mathrm{ml}$ ) (Jensen et al. 1996). Sediment samples were supplemented with sterile seawater and vortexed prior to plating. Seawater samples were plated without further dilution immediately after collection. All media were supplemented with $50 \mu \mathrm{g} \mathrm{ml}^{-1}$ cycloheximide to inhibit fungal growth and $100 \mu \mathrm{g} \mathrm{ml}^{-1}$ ampicillin to select for planctomycetes over bacteria that possess peptidoglycan as a cell wall component. Plates were inspected at weekly intervals for up to several months. Following repeated single-colony isolation on ampicillin-containing media, a total of 116 strains were obtained in pure culture and deposited in a strain collection.

Fluorescence in situ hybridization (FISH) In order to screen the strain collection for the presence of planctomycetes, FISH was performed using Planctomycetespecific Probe Pla46 (Table 1). The universal probe mix EUB338, EUB338-II and EUB338-III targeting the domain Eubacteria served as a control that sufficient microbial biomass had adhered to the microscope slides (Daims et al. 1999). Bacterial isolates were fixed overnight in $4 \%$ paraformaldehyde-PBS (phosphatebuffered saline) at $4^{\circ} \mathrm{C}$. Following centrifugation at $10000 \mathrm{rpm}(12000 \times \mathrm{g})$ (Biofuge Heraeus), the cells were washed $2 \times$ with PBS. We applied $25 \mu$ l of the cell suspension to microscope slides with grooves, and heat-fixed at $37^{\circ} \mathrm{C}$. The slides were dehydrated in an aqueous ethanol series $(50,80$ and $96 \%$ ) for $3 \mathrm{~min}$ each, dried, and stored at $-20^{\circ} \mathrm{C}$ prior to use. Oligonucleotide probes were applied to slides $(1 \mu \mathrm{l})$ at a final concentration of $3 \mathrm{ng}$ of labelled probe $\mathrm{\mu l}^{-1}$ hybridization buffer (MWG, Biotech). Hybridization of sponge tissue cyrosections was performed as described previously by Friedrich et al. (2001). Each probe was applied to at least 5 different tissue sections of 1 sponge. More than 5 different Aplysina aerophoba and A. fistularis specimens were investigated. In situ hybridization and microscopical visualization were performed as described elsewhere (Manz et al. 1992, Friedrich et al. 2001).

Cloning, sequencing and phylogenetic analysis. DNA extraction, PCR amplification, cloning and sequencing of the 16S rRNA genes were performed following the methods of Hentschel et al. (2001). For PCR amplification, the universal primers $27 \mathrm{f}$ (5'GAGTTTGATCCTGGCTCA'3) and 1385r (5'CGGTGTGT(A/G)CAAGGCCC'3) according to Escherichia coli 16S rDNA numbering were used (Lane 1991). Nearly complete 16S rRNA gene sequences were aligned using the ABI Prism Autoassembler Version 2.1 software (Perkin Elmer) and compared to known sequences in 
Table 1. Oligonucleotide probes used for in situ hybridization. FA: formamide concentration of hybridization buffer

\begin{tabular}{|c|c|c|c|c|c|}
\hline Probe & Sequence $5^{\prime} \rightarrow 3^{\prime}$ & $\%$ FA & Specificity & $\begin{array}{l}\text { rRNA position } \\
\text { scherichia coli }\end{array}$ & Source \\
\hline \multicolumn{6}{|c|}{ Domain-specific probe mix } \\
\hline EUB338 & GCTGCCTCCCGTAGGAGT & 35 & Domain Eubacteria & $338-355$ & Amann et al. (1995) \\
\hline EUB338-II & GCAGCCACCCGTAGGTGT & & & & Daims et al. (1999) \\
\hline EUB338-III & GCTGCCACCCGTAGGTGT & & & & Daims et al. (1999) \\
\hline \multicolumn{6}{|c|}{ Phylum-specific probe } \\
\hline Pla46 & GACTTGCATGCCTAATCC & 30 & Phylum Planctomycetes & $46-63$ & Neef et al. (1998) \\
\hline \multicolumn{6}{|c|}{ Order-specific probe } \\
\hline Pla8863 & GCCTTGCGACCATACTTCCC & 35 & Order Planctomycetales & $886-904$ & Neef et al. (1998) \\
\hline Competitor & GCCTTGCGACCGTACTCCC & & & & \\
\hline \multicolumn{6}{|c|}{ Strain-specific probes } \\
\hline Pir197 & CTCGAGCGGAATCTCACCAT & $\Gamma 30$ & Strain Pirellula sp. 797 & $197-216$ & K. H. Schlesner (pers. comm.) \\
\hline Pir81 & GTCCCCTTAGAAGCAAGC & 30 & Strain Pirellula sp. 81 & $81-98$ & Present study \\
\hline
\end{tabular}

the NCBI (National Center for Biotechnology Information) GenBank database using the basic local alignment search tool (BLAST) algorithm (Altschul et al. 1990) The sequences of the isolates were aligned with the closest neighbors using CLUSTAL W (Thompson et al. 1994). Phylogenetic trees were constructed using the Kitsch algorithm (Fitsch-Margoliash and leastsquares method with evolutionary clock) from the PHYLIP program (Felsenstein 1993). Chlamydia psittaci was used as an outgroup. CLUSTAL W and PHYLIP were accessed through the website of the Computing Center of Pasteur Institute (see: http:// bioweb.pasteur.fr). The sequences were deposited in the NCBI GenBank under Accession Nos. AF453518 to AF453520.

Design of strain-specific FISH probe. A strainspecific probe for the sponge-derived Pirellula sp. Strain 81 was designed during the ARB workshop (September 2001) using the ARB software package (O. Stunk \& W. Ludwig (available at http://www.mikro. biologie.tu-muenchen.de). The hybridization stringency was adjusted such that Pirellula sp. 81 yielded bright signals whereas non-target organisms that contained 1 to a few mismatches in the 16S rRNA target region ( $P$. marina, Pirellula sp. 16, Pirellula sp. 797) did not.

Transmission electron microscopy. Following cultivation of the isolates in liquid medium, bacterial biomass was fixed in $50 \mathrm{mM}$ cacodylate $/ 2.5 \%$ glutaraldehyde in artificial seawater (ASW) for $24 \mathrm{~h}$. Following centrifugation $(1800 \times g$ for $10 \mathrm{~min})$ and washing with PBS, the samples were postfixed in $2 \%$ osmium tetroxide/3 $\times$ PBS for $24 \mathrm{~h}$. They were dehydrated in an ethanol series $(50,70,80,90,3 \times 100 \%$, each for $1 \mathrm{~h}$ ) and subsequently incubated in propylene oxide $(3 \times$ $1 \mathrm{~h})$. Following overnight incubation in 1:1 (v/v) propy- lene oxide/glycidether 100 (Epon 812; Roth) and 2 additional $3 \mathrm{~h}$ incubation steps in glycidether, the resin was polymerized at $60^{\circ} \mathrm{C}$ for $3 \mathrm{~d}$. The samples were sectioned with an ultramicrotome (OM U3, C. Reichert) and contrasted with $1 \%$ uranyl acetate and lead citrate. Sections were examined with a Zeiss EM 10 electron microscope operating at $80 \mathrm{kV}$. Transmission electron microscopy (TEM) on sponge tissues was performed as described previously (Friedrich et al. 2001).

\section{RESULTS AND DISCUSSION}

Screening of the strain collection using the planctomycete-specific probe Pla46 revealed 3 positive candidates. Isolate 797 was obtained from the Mediterranean sponge Aplysina aerophoba, Isolate 81 from the Caribbean sponge $A$. fistularis and Isolate 16 was recovered from Caribbean seawater. The fluorescence signal of individual cells of all strains appeared in a ring-shaped manner that is consistent with the presence of a highly condensed nucleoid, as is characteristic of the genus Pirellula (Neef et al. 1998). As expected, the positive control $P$. marina produced a similar ring-shaped fluorescence, whereas the negative control Escherichia coli produced no signal. These findings demonstrate that planctomycetes can be cultivated from marine sponges.

Nearly complete 16S rRNA gene-sequencing revealed that all isolates of this study belonged to the genus Pirellula (Fig. 1). The Mediterranean sponge isolate, 797, is most closely related to Pirellula sp. Schlesner 1 from the Kiel Bight (>99.1\% sequence similarity) and to Planctomycete Strain 608 from Hawaii (98.4\% sequence similarity). Caribbean Sponge Isolate 81 is most closely related to a group of 


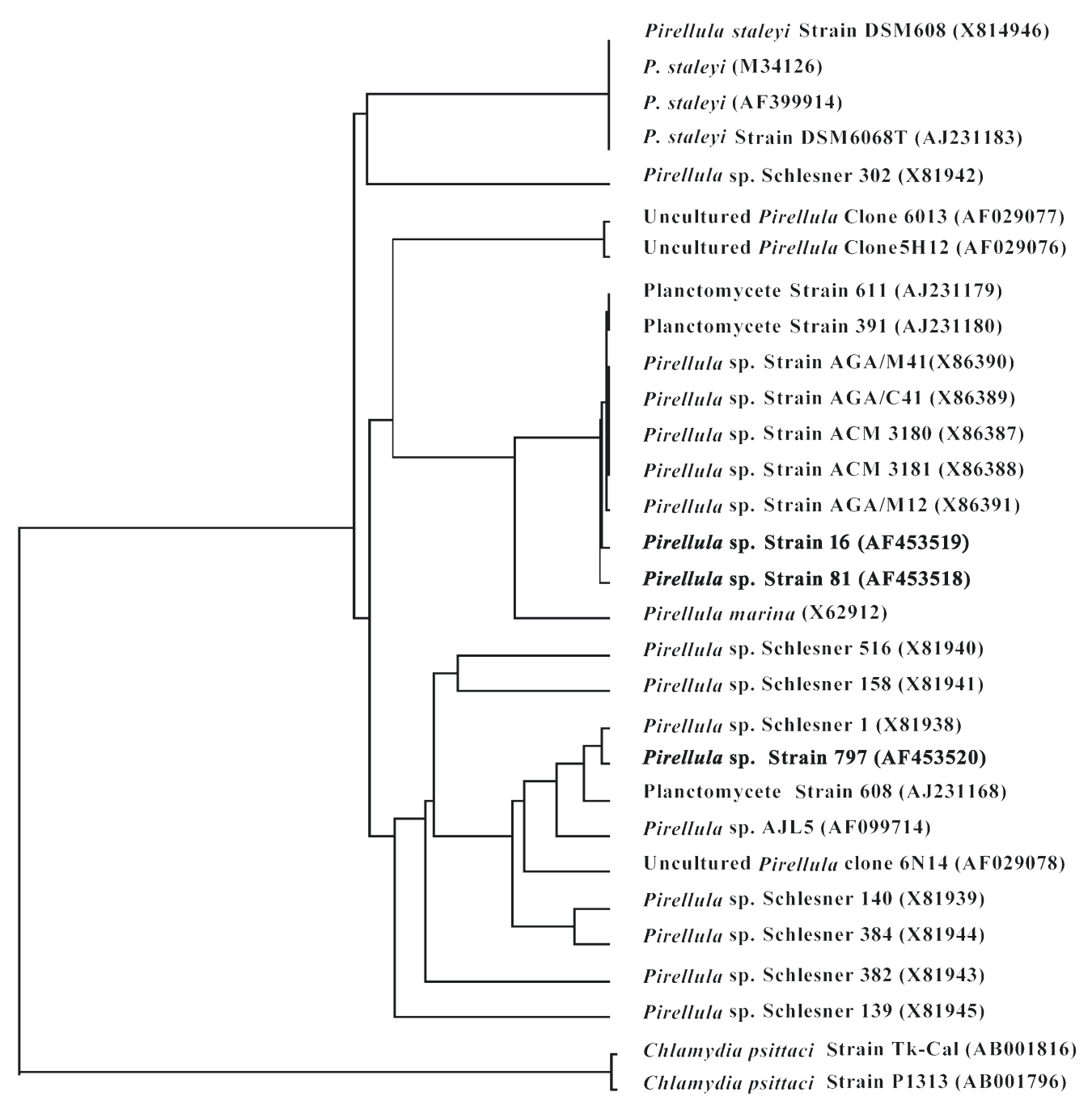

Fig. 1. Phylogenetic tree derived using Fitch-Margoliash and least-squares method with an evolutionary clock from DNADIST of PHYLIP. Database accession numbers are shown in parentheses. Strains in bold face: isolates obtained during present study

non-pigmented Pirellula sp. strains isolated from giant tiger prawn postlarvae (>99.0\% sequence similarity), to Planctomycete Strains 391 and 611 (>98.9\% sequence similarity) and to the Caribbean seawater isolate 16 (98.1\% sequence similarity). Mediterranean Isolate 797 and Caribbean Isolates 16 and 81 fall within 2 distinct phylogenetic clusters within the genus Pirellula. The generally accepted phylogenetic definition of a species states that strains must show $>97 \%$ 16S rRNA sequence similarity (Stackebrandt \& Goebel 1994). Interestingly, the sequence similarities of both Mediterranean (Isolate 797) and Caribbean (Isolate 16, 81) isolates to the most closely related previously described Pirellula sp., P. marina, are quite low (89.1\%; and 92.4 and $93.1 \%$, respectively), supporting previous suggestions that they may constitute new Pirellula species (Fuerst et al. 1997).
The affiliation of the sponge isolates to the genus Pirellula is supported by their colony appearance and by morphological characteristics documented in this study and reported elsewhere (Staley et al. 1992, Fuerst 1995, Fuerst et al. 1997). Pirellula sp. Isolate 797 grew slowly on M30a medium (approximately $1.0 \mathrm{~mm}$ colony diameter after $3 \mathrm{wk}$ ) with $N$-acetylglucosamine as the sole carbon and nitrogen source. This observation suggests that this strain is capable of chitin degradation, as has been previously reported for Planctomycetes (Schlesner 1994, Fuerst 1995). The colonies were pink-pigmented, opaque, circular, glistening and pulvinate, with an entire edge. In contrast, Isolates 16 and 81 grew slowly only on M13 medium (approximately $0.7 \mathrm{~mm}$ colony diameter after $3 \mathrm{wk}$ ). These colonies were non-pigmented, opaque, circular, glistening and flat, with an entire edge. The fact that 


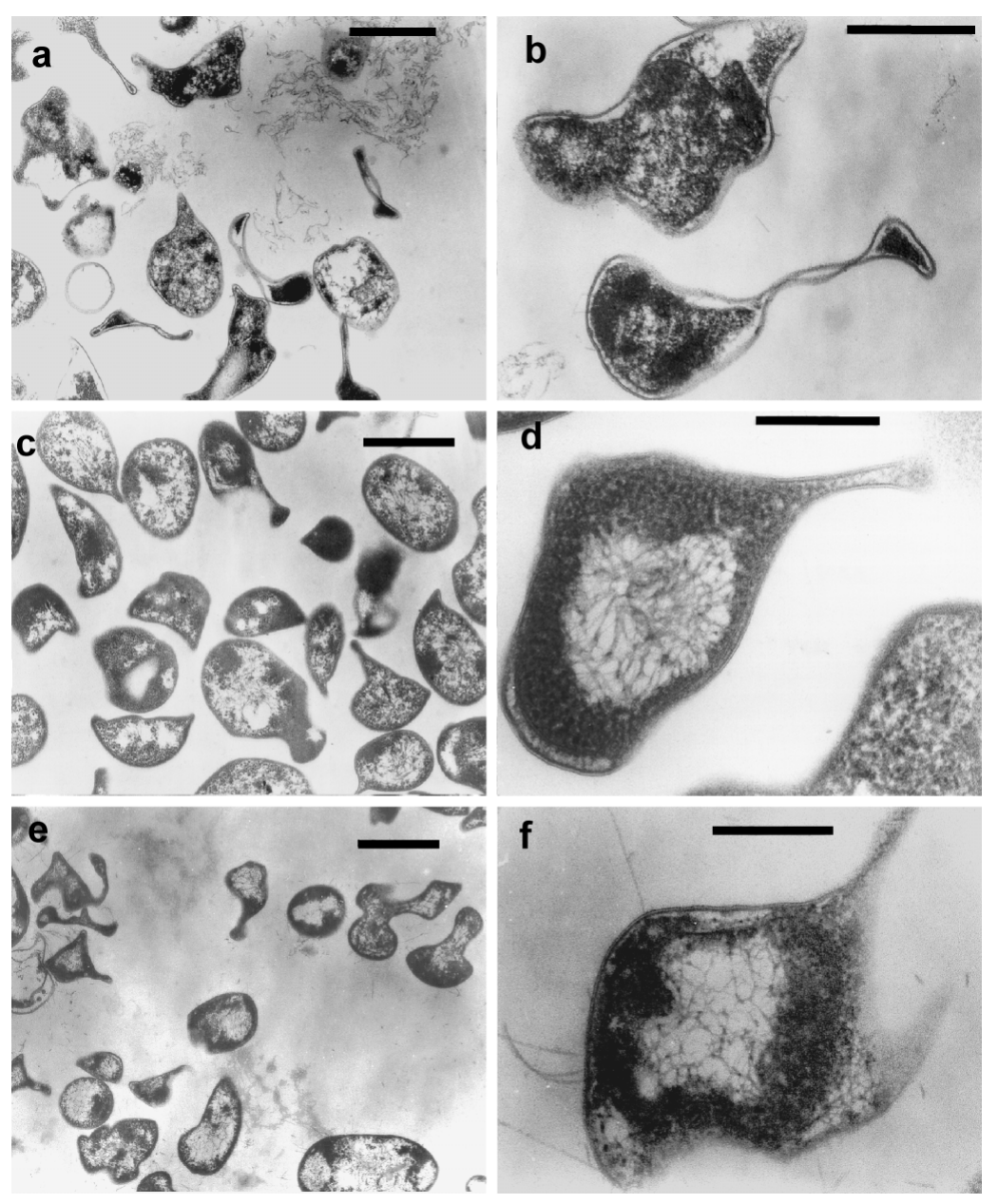

Fig. 2. Pirellula marina (a,b) and Pirellula sp. Strains $81(\mathrm{c}, \mathrm{d})$ and $16(\mathrm{e}, \mathrm{f})$. Transmission electron microscopy. Scale bars $=1 \mu \mathrm{m}(\mathrm{a}, \mathrm{c}, \mathrm{e})$, $0.5 \mu \mathrm{m}(\mathrm{b})$ and $0.25 \mu \mathrm{m}(\mathrm{d}, \mathrm{f})$

P. marina (positive control) (Fig. 2a,b); $1.20 \pm 0.28 \mu \mathrm{m}$ (length) $\times 0.72 \pm 0.29 \mu \mathrm{m}$ (width) $(\mathrm{n}=12)$ for Pirellula sp. 81 (Fig. 2c,d); $0.99 \pm 0.33 \mu \mathrm{m}$ (length) $\times 0.59$ $\pm 0.16 \mu \mathrm{m}$ (width) $(\mathrm{n}=16)$ for Pirellula sp. 16 (Fig. 2e,f). Pirellula sp. Isolate 16 showed fibrillar appendages (Fig. 2f). The condensed nucleoid contained thin filaments that were easily discernible in the enlargements in Fig. 2d,f). The characteristic, stain-accumulating crateriform structures were only visible on the cell surface of negatively stained cells and could therefore not be identified.

In agreement with previous studies (Friedrich et al. 2001), hybridization of Aplysina aerophoba tissues with Planctomycete-specific Probe Pla46 resulted in abundant fluorescent signals (Fig. 3a). Hybridization of A. fistularis tissues with the probe Pla46 resulted in consistent, but somewhat lower, abundances (Fig. 3b). Similar results were obtained with Planctomycetales-specific
Isolate 797 exhibited different phenotypic characteristics than the other 2 isolates (16 and 81) corroborates the phylogenetic identification of 2 discrete clusters within the genus Pirellula. The fact that closely related strains were recovered from a sponge sample and the surrounding seawater suggests that at least Pirellula sp. Strain 81 is not specifically associated with Aplysina fistularis.

TEM observations revealed the ovoid, pear- or droplet-shaped cell morphology that is characteristic of the genus Pirellula (Fig. 2). The size of the cells was: $1.12 \pm 0.25 \mu \mathrm{m}$ (length) $\times 0.56 \pm 0.27 \mu \mathrm{m}$ (width) $(\mathrm{n}=12)$ for

Fig. 3. Aplysina aerophoba $(\mathrm{a}, \mathrm{c})$ and A. fistularis $(b, d)$. Fluorescence in situ hybridization of tissue cryosections with $(\mathrm{a}, \mathrm{b})$ Planctomycete-specific Probe Pla46, (c) Strain-specific Probe Pir197, and (d) Strain-specific Probe Pir81
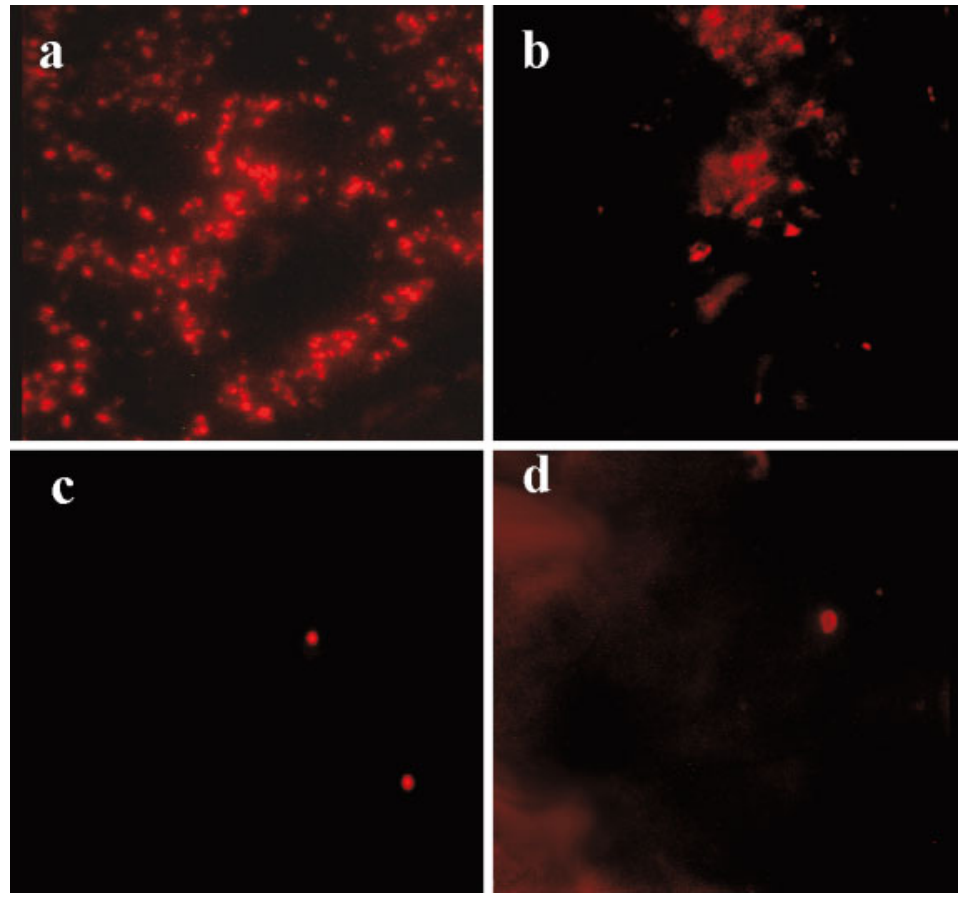
Probe Pla886c, albeit some unspecific background binding was noted (data not shown). In order to assess whether Pirellula sp. Strains 797 and 81 constitute a significant fraction of the sponge-associated bacterial community, strain-specific FISH probes were applied (Table 1). However, hybridization of $A$. aerophoba tissue cryosections with Probe Pir197 resulted in the detection of only a few fluorescent cells (Fig. 3c). Similarly, only a few cells were detected following hybridization of $A$. fistularis tissue cryosections with the newly designed Probe Pir81 (Fig. 3d). Here, the fluorescent signal resembled the ring-shaped structure indicative of cell compartmentalization. The application of Probe Pir197 to A. fistularis and of Probe Pir81 to A. aerophoba did not produce fluorescent signals (data not shown).

In summary, the application of FISH using strainspecific probes revealed that the isolated Pirellula sp. Strains 797 and 81 did not match the abundance of cells detectable with the Planctomycete-specific Probe Pla46. Apparently, the standard culture methods applied in this study are not adequate for the majority of planctomycete bacteria that can be visualized by FISH in the Aplysina sponge species examined. The data of this study are consistent with the observation that 16S rDNA library construction from sponges does not yield planctomycete sequences (Webster et al. 2001, Hentschel et al. 2002, 2003). The discrepancies between culturable and nonculturable approaches to natural microbiological communities are a common phenomenon in microbial ecology (Amann et al. 1995) and demonstrate a pressing need for the development of new, innovative methods for culturing marine bacteria (for novel methods see Zengler et al. 2002). Finally, the phylogenetic identity of the elusive fraction of sponge-associated microorganisms that shows highly unusual cell compartmentalization in the form of nucleoid-containing bodies remains to be elucidated.

Acknowledgements. We gratefully acknowledge the marine operations personnel at the Laboratoire Arago (Banyuls-surMer, France) and the captain and crew of the RV 'Seaward Johnson' (HBOI, Florida) for their expert help during sponge collection. We thank D. Gade (MPI für Marine Mikrobiologie, Bremen) and K. H. Schlesner (Institut für Mikrobiologie, Universität Kiel) for the isolation of Pirellula sp. Strain 797 from Aplysina aerophoba and for providing us with FISH Probe PiR197. We also thank J. R. Pawlik (University of North Carolina, Wilmington) for excellent cruise organization, C. A. Kauffman for technical assistance on board ship, G. P. Concepcion (Marine Science Institute, University of the Philippines) for bioassay facilities, and W. L. Barraquio (Institute of Biology, University of the Philippines) for assistance with photography of the isolates. This work was generously supported by grants to U.H. (SFB567 and bmb+f grant 'Biotec-Marin') and to S.P.-E. (DAAD research fellowship).

\section{LITERATURE CITED}

Altschul SF, Gish W, Miller W, Myers EW, Lipman DJ (1990) Basic local alignment search tool. J Mol Biol 215:403-410

Amann R, Ludwig W, Schleifer KH (1995) Phylogenetic identification and in situ detection of individual microbial cells without cultivation. Microbiol Rev 59:143-169

Daims H, Brühl A, Amann R, Schleifer KH, Wagner M (1999) The domain-specific probe EUB 338 is insufficient for the detection of all Bacteria: development and evaluation of a more comprehensive probe set. Syst Appl Microbiol 22: 434-444

Derakshani M, Lukow T, Liesack W (2001) Novel bacterial lineages at the (sub) division level detected by signature nucleotide-targeted recovery of 16S rRNA genes from bulk soil and rice roots of flooded rice microcosms. Appl Environ Microbiol 67:623-631

Felsenstein J (1993) PHYLIP-Phylogeny inference package, Version 3.5c. J Felsenstein, Department of Genetics, University of Washington, Seattle

Friedrich AB (1998) Bakterien des Schwammes Aplysina cavernicola: Detektion, Charakterisierung und phylogenetische Einordnung. MS thesis, Universität Würzburg

Friedrich AB, Merkert H, Fendert T, Hacker J, Proksch P, Hentschel U (1999) Microbial diversity in the marine sponge Aplysina cavernicola (formerly Verongia cavernicola) analyzed by fluorescence in situ hybridization (FISH). Mar Biol 134:461-470

Friedrich AB, Fischer I, Proksch P, Hacker J, Hentschel U (2001) Temporal variation of the microbial community associated with the Mediterranean sponge Aplysina aerophoba. FEMS Microbiol Ecol 38:105-113

Fuerst JA (1995) The planctomycetes: emerging models for microbial ecology, evolution and cell biology. Microbiology (Wash DC) 141:1493-1506

Fuerst JA, Gwilliam HG, Lindsay M, Lichanska A, Belcher C, Vickers JE, Hugenholtz P (1997) Isolation and molecular identification of planctomycete bacteria from post larvae of the giant tiger prawn, Penaeus monodon. Appl Environ Microbiol 63:254-262

Fuerst JA, Webb RI, Garson MJ, Hardy L, Reiswig HM (1998) Membrane-bounded nucleoids in microbial symbionts of marine sponges. FEMS Microbiol Lett 166:29-34

Fuerst JA, Webb RI, Garson MJ, Hardy L, Reiswig HM (1999) Membrane-bounded nuclear bodies in a diverse range of symbionts of Great Barrier Reef sponges. Mem Queensl Mus 44:193-203

Hentschel U, Schmid M, Wagner M, Fieseler L, Gernert C. Hacker J (2001) Isolation and phylogenetic analysis of bacteria with antimicrobial activities from the Mediterranean sponges Aplysina aerophoba and Aplysina cavernicola. FEMS Microbiol Ecol 35:305-312

Hentschel U, Hopke J, Horn M, Friedrich AB, Wagner M, Hacker J, Moore BS (2002) Molecular evidence for a uniform microbial community in sponges from different oceans. Appl Environ Microbiol 68:4431-4440

Hentschel U, Fieseler L, Wehrl M, Gernert C, Steinert M, Horn M, Hacker J (2003) Microbial diversity of marine sponges. In: Müller WEG (ed) Molecular marine biology of sponges. Springer-Verlag, Heidelberg, p 59-88

Jensen PR, Kauffman CA, Fenical W (1996) High recovery of culturable bacteria from surfaces of marine algae. Mar Biol 126:1-7

Lane DJ (1991) 16S/23S rRNA sequencing. In: Stackebrandt E, Goodfellow M (eds) Nucleic acid techniques in bacterial systematics. John Wiley \& Sons, Chichester, p 115-175 Liesack W, Stackebrandt E (1992) Occurrence of novel groups 
of the domain Bacteria as revealed by analysis of genetic material isolated from an Australian terrestrial environment. J Bacteriol 174:5072-5078

Lindsay MR, Webb RI, Fuerst JA (1997) Pirellulosomes: a new type of membrane-bounded cell compartment in planctomycete bacteria of the genus Pirellula. Microbiology (Wash DC) 143:739-748

Lindsay MR, Webb RI, Strous M, Jetten MS, Butler MK, Forde RJ, Fuerst JA (2001) Cell compartmentalization in planctomycetes: novel types of structural organization for the bacterial cell. Arch Microbiol 175:413-429

Manz W, Amann R, Ludwig W, Wagner M, Schleifer KH (1992) Phylogenetic oligodeoxynucleotide probes for the major subclasses of proteobacteria: problems and solutions. Syst Appl Microbiol 15:593-600

Neef A, Amann R, Schlesner H, Schleifer KH (1998) Monitoring a widespread bacterial group: in situ detection of planctomycetes with 16S rRNA-targeted probes. Microbiology (Wash DC) 144:3257-3266

Santavy DL, Willenz P, Colwell RR (1990) Phenotypic study of bacteria associated with the Caribbean sponge Ceratoporella nicholsoni. Appl Environ Microbiol 56: $1750-1762$

Schlesner H (1986) Pirella marina sp. nov., a budding, peptidoglycanless bacterium from brackish water. Syst Appl Microbiol 8:177-180 (1986)

Schlesner H (1994) The development of media suitable for the microorganisms morphologically resembling Planctomyces spp., Pirellula spp., and other Planctomycetales from various aquatic habitats using dilute media. Syst Appl Microbiol 17:135-145

Stackebrandt E, Goebel BM (1994) Taxonomic note: a place

Editorial responsibility: Gerhard Herndl,

Den Burg, Texel, The Netherlands for DNA-DNA reassociation and 16S rRNA sequence analysis in the present species definition in bacteriology. Int J Syst Bacteriol 44:846-849

Staley JT, Fuerst JA, Giovannoni S, Schlesner H (1992) The order Planctomycetales and the genera Planctomyces, Pirellula, Gemmata and Isosphaera. In: Balows A, Trüper HG, Dworkin M, Harder W, Schleifer KH (eds) The prokaryotes: a handbook on the biology of bacteria: ecophysiology, isolation, identification, applications, 2nd edn. Springer-Verlag, New York, p 3710-3731

Thompson JD, Higgins DG, Gibson TJ (1994) CLUSTAL W: improving the sensitivity of progressive multiple sequence alignment through sequence weighting, position-specific gap penalties and weight matrix choice. Nucleic Acids Res 22:4673-4680

Vacelet J (1975) Étude en microscopie électronique de l'association entre bactéries et spongiaires du genre Verongia (Dictyoceratida). J Microsc Biol Cell 23:271-288

Wang J, Jenkins C, Webb RI, Fuerst JA (2002) Isolation of Gemmata-like and Isosphaera-like planytomycete bacteria from soil and freshwater. Appl Environ Microbiol 68: $417-422$

Ward N, Rainey FA, Stackebrandt E, Schlesner H (1995) Unraveling the extent of diversity within the order Planctomycetales. Appl Environ Microbiol 61:2270-2275

Webster NS, Wilson KJ, Blackall LL, Hill RT (2001) Phylogenetic diversity of bacteria associated with the marine sponge Rhopaloeides odorabile. Appl Environ Microbiol 67:434-44

Zengler K, Toledo G, Rappe M, Elkins J, Mathur EJ, Short JM, Keller M (2002) Cultivating the uncultured. Proc Natl Acad Sci USA 99(24):15681-15686

Submitted: March 10, 2003; Accepted: July 16, 2003

Proofs received from author(s): October 8, 2003 